\title{
MORPHOLOGICAL AND METABOLIC CHANGES CAUSED BY SYNDROME OF ISCHEMIA-REPERFUSION, AND FEATURES OF ITS THERAPEUTIC INFLUENCE
}

\author{
@N. V. Volotovska, A. Yu. Hodovana, D. Nkansah Appiah \\ I. Horbachevsky Ternopil State Medical University
}

SUMMARY. The article analyzes literary sources regarding the causes and characteristics of the development of ischemia-reperfusion syndrome, as well as manifestations of pathophysiological changes under the influence of environmental factors. The influence of treatment and prophylactic measures aimed at reducing the damage is investigated.

An influx of oxygenated blood which contains nutrients is imperative for the nutrition of each organ. Ischemia, being a condition of limiting or stopping of blood supply, has many causes - acute and chronic.

Changes that cause ischemia can develop for decades (cardiovascular and cerebrovascular diseases). There are also those that arise against the backdrop of a relatively short period of time and are associated with a sudden cessation of blood supply (embolism, thrombosis, long-term compression syndrome and one of its variants - complications arising from the use of a hemostatic tourniquet, as well as a tourniquet for blood supply stoppage in organ during surgery).

The type of ischemia that leads to the restoration of blood flow, causes a special phenomenon, when restoring the blood supply of ischemic tissue and it leads also to quite expressed tissues' damage than those that occur on the background of isolated ischemia. This phenomenon is called the syndrome of ischemia-reperfusion. Acute limb ischemia has such symptoms as pain, edema, loss of function and violation of nerve condition. But in complicated state it can cause damaging of the whole body.

KEY WORDS: ischemia; ischemia-reperfusion; bleeding; tourniquet; skeletal muscle; experiment; necrosis; apoptosis.

Introduction. The phenomenon of ischemiareperfusion (IR) is a complex of pathological relationships and influences that arise between tissues and entire organ systems.

Starting from the completely inverse recovery of damaged cells to the syndrome of systemic inflammatory response (SIRS) and the occurrence of multiple organ dysfunction (SMOD), which is a clinical manifestation of a particular etiological effect of the IRsyndrome. At the same time, according to literature data, SIRS and SMOD are responsible for $35-40 \%$ of fatal cases in the background of IR-syndrome [1].

The aim of the study - to systematize the causes and features of the syndrome of ischemia-reperfusion, as well as the manifestations of pathophysiological changes under the influence of environmental factors.

Material and Methods. Emphasis is made on the pathogenesis of ischemia-reperfusion in the context of the infection of internal organs. Changes in morphology (morphometry) and metabolic violations are evaluated. Since the end of the XX century, many researches have been dedicated to the impact of tourniquet in general and the syndrome of IR on its background particularly. Thus, it has been proved that the tourniquet contributed to the metabolic changes' in the tissues, namely in muscles. Violation of the body's general state is also the subject of many scientific researches [2].

IR is characterized by activation of the lipid peroxidation and complement system, leukocyte-endothelial cellular adhesion, platelet-leukocyte aggre- gation and increased microvascular permeability. Under the most severe form of IR, it can lead to multiple organs' failure and death $[3,4,5]$.

IR is a complex phenomenon that includes not only intracellular injuries, but also damaging inflammatory response. Both of these processes are an integral part of the pathogenetic networks. Anoxic cell injury predominates in the ischemic phase. The reduced mitochondrial ATP generations violate cell ion homeostasis with activation of hydrolases and a decrease of selective permeability of cell membrane. The immune response is initiated to resupply lack of blood. Resident cells of the damaged tissue, derivatives of blood cells and extracellular elements, such as the complement system are activated and other molecules are activated by alterate pathways. Cellular damage that occurs in the reperfusion phase may either be the result of cellular alterations that has already occurred in the ischemic stage, or may be from the consequence of the inflammatory response. Intracellular damages are in part the same as those involved in anoxic cell injury. In addition, activation of intracellular signaling cascades and apoptotic mechanisms may take place [6].

It has been experimentally confirmed that in the pathogenesis of myocardial infarction, due to IR, there are many pathways, including disorders of the ion channels' activity, growth of active forms of oxygen, inflammation and endothelial dysfunction [7]. Research of experimental myocardial infarction in rats by a group of scientists has shown that a combination of sevoflurane with pre-ischemic preparation 
Огляди літератури, оригінальні дослідження, погляд на проблему, ювілеї

protected rats from myocardial injury induced by ischemia and reperfusion partially via inhibition of TLR4 / MyD88 / NF -KB signaling pathway, significantly reduced the size of myocardial damage, reduced secretion of inflammatory cytokines and the expression of proapoptic factors but led to activation of anti-inflammatory agents [8].

During liver damage after "warm" hepatic ischemia sinusoidal endothelial cells and hepatocytes are first targets in the early "cytotoxic" phase. At this time, apoptosis and cell necrosis remain. It is believed that Kupffer cells can play an important role in initiating the cytotoxic effect on liver cells, and they are a source of reactive oxygen species and proinflammatory mediators, especially the tumor necrotic factor-Alpha. Disruptions of microcirculatory are a consequence of the imbalance between vasoconstrictors and vasodilators, such as nitric oxide. This leads to reperfusion damage. There is an averment that the initial period of IR has hepatoprotective effects and can be reproduced with drugs that cause oxidative stress, as well as with IL-6 and TNF [9]. Oxygen-derived free radicals have been implicated as a mediator of the microvascular and parenchymal cell injury associated with reperfusion of ischemic tissues $[10,11]$.

During ischemia caused by a hemostatic tourniquet, the following complications are mostly observed: ischemia and damage to the nerves in the pressure zone of tourniquet, edema of limb, pallor of skin, weakness of muscles without paralysis, pain $[12,13]$. Although the turnstile is an effective tool for fast stopping of critical bleeding, its use within 2-3 hours can trigger irreversible processes of dying out of tissues due to stop of bleeding and, in difficult cases, to limb amputation [14].

Three days after 4 hours of ischemia, $46 \%$ of the cross-sectional area of affected muscle were identified as necrotic. And after 4,5 hours - necrosis increased to $75 \%$ [15].

The concentration of glycolytic metabolites and the content of high energy phosphates in skeletal muscle were analyzed after various times of tourniquet ischemia during operation in bloodless field. On the background of moderate growth in the ischemic limb of phosphocreatine, an expressed increase of lactate (in 4-5 times) was observed. Obviously, the reason for a moderate increase in glucose and glucose-6-phosphate was the activation of glycogenolysis. Since ischemia lasted from 30 to 90 minutes in these cases, then changes of indexes were detected after 5 minutes [16].

Similar results about extraordinary growth (in 14 times) of lactate were received by another group of scientists. Also, they determined decrease of skin temperature from 35.9 to 33.5 degrees, which quickly dropped to that level in the first 15 minutes, after which it was held at this level [17].
In research of the electrolytes' content, the maximum increase of plasma potassium in the operated leg was observed in the first minutes after tourniquet release. However, the total and intracellular concentration of this electrolyte, as well as sodium, did not significantly changed [18]. Also it was revealed that the gas pressure in the tissues is a more sensitive method for evaluating hypoxia on IR after tourniquet than the evaluation of the partial pressure of gases in venous blood of the ischemic limb [19].

Research of interstitial pressure have shown that after two hours in both examined muscles, it was significantly increased although in the early acute period (up to 24 hours), depending of the group of muscles, the difference in the values of partial pressure $\mathrm{O} 2$ and $\mathrm{CO} 2$ was marked. Swelling and metabolic changes depended on the anatomical area on which the tourniquet has pressed. Also, the level of glucose and phosphocreatine has significantly decreased, whereas glucose phosphate and lactate increased significantly [20].

Interesting and extensive data of the treatment and prevention of complications of IR-limb syndrome are available.

The decrease of the temperature from 24 to 22 degrees caused necrotic lesions of the shin muscle of the experimental rats from $80 \%$ to $29 \%$. That was equivalent to a reduction of ischemia duration for 30 minutes. So, it is important to consider both in the modeling of experimental violation and in prevention measures [21]. Another research has shown that moderate cooling in initial ischemia (up to 20 degrees) effectively protects against post-ischemical necrotic muscle changes, while cooling on the reperfusion background does not have such an effect [22].

Thus, thrombolysis in acute limb ischemia became the first-line therapy, although in some cases surgical intervention is also required. Treatment with tissue plasminogen activator is used in many circuits for this purpose [23]. In this case, other scientists advise to apply controlled reperfusion with low pressure perfusion in the low temperature conditions. It is also advisable to use a leukocyte filter. The initial reperfusate should be hyperosmolar, hypocalcemic, have a moderate alkaline $\mathrm{pH}$, and contains free radical scavengers, for example, allopurinol [24].

These recommendations are ultimately relevant for patients with the effects of turnstiles. Among latest data there are application of adrenomedullin and vascular endothelial growth factor in experimental rats [25], which improved antioxidant protection and had some protective effect on the skeletal muscle of animals; the protective effect of one of three mammalian signal transduction proteins and the gene encoding it (Sonic Hedgehog) on the 
Огляди літератури, оригінальні дослідження, погляд на проблему, ювілеї

background of ischemia-reperfusion in skeletal muscle of rats has been proved [26].

Another group of scientists emphasizes that in order to improve experimental animals state it, is important to reduce the emigration of activated leukocytes, which, in fact, was achieved by entering with therapeutic aim for animals of "Daphlon-500" remedy [27]. Antioxidant medication may help to lower ischemia reperfusion injury [28].

In experimental results of researchers group, which practiced the entering of pentoxifylline before, during and after the ischemic period, significant necrotic changes were observed in the muscles of both groups (treated and non-treated), but they were less expressed on the pentoxifylline background. So, they concluded, effect of pentoxifylline is similar to therapeutic effect of hypothermia [29].

Also, entering of pentoxifylline in the early reperfusion period (after 4 hours) in a model of unilateral hindlimb ischemia reperfusion injury had positive therapeutic effect on reduction of cellular necrosis, degeneration of renal tubules, and glomerular size, whereas the effect was lost after 24 hours of reperfusion [30]. The application of cilostazole (platelet aggregation inhibitor) on the background of abdominal aortic ligature did not give any therapeutical effect. Interstitial edema, inflammatory infiltrates formation, hypereosinophilia fiber, cariopicnose and necrosis in rats' muscle of the hind limb were detected, as well as in the control group [31].

The usage of vardenafil (phosphodiesterase- 5 inhibitor) has shown a protective effect on the kidneys and a creatinine level on the background of acute ischemia-reperfusion, resulted from ligature of the left renal pedicle [32].

IR treatment may be broken by the fact that inhibition of IR-associated inflammation may, in turn, interfere with protective physiological responses or lead to immunosuppression [5, 33].

Conclusion. Analysis of the ischemia-reperfusion syndrome features, especially on the background of the hemostatic turnstile, is still relevant. New issues are emerging constantly, so it makes further researches necessary.

\section{LITERATURE}

1. Abela C. B. Clinical implications of ischaemia-reperfusion injury / B. C. Abela, S. Homer-Vanniasinkham // Pathopysiology. - 2003. - Vol. 9. - P. 229-240.

2. Acute and delayed effects of tourniquet ischemia on subfascial pressures and tissue gas tensions within muscles of the subhuman primate limb / G. J. Price, S. H. Miller, T. J. Kennedy, W. P. Graham // Surgical Forum. 1978. - Vol. 29. - P. 612-615.

3. Development of "no-reflow" phenomenon in ischemia/reperfusion injury: failure of active vasomotility and not simply passive vasoconstriction / J. Nanobashvili, C. Neumayer, A. Fuegl [et al.] // European Surgical Research Journal. - 2003. - Vol. 35. - P. 417-424.

4. Development of 'no-reflow' phenomenon in ischemia/reperfusion injury: failure of active vasomotility and not simply passive vasoconstriction / J. Nanobashvili, C. Neumayer, A. Fuegl [et al.] // European Surgical Research Journal. - 2003. - Vol. 35 (5). - P. 417-424.

5. Eltzschig H. K. Vascular ischaemia and reperfusion injury / H. K. Eltzschig, C. D. Collard // British Medical Bulletin. - 2004. - Vol. 70 (1). - P. 71-86.

6. Groot de H. Ischemia-Reperfusion Injury: Processes in Pathogenetic Networks: A Review / H. de Groot, U. Rauen // Transplantation Proceedings. - 2007. - Vol. 39, Issue 2. P. 481-484.

7. Pathogenesis of myocardial ischemia-reperfusion injury and rationale for therapy / T. Aslan, M. D. Turer, A. Joseph. M. D. Hill // The American Journal of Cardiology. 2010. - Vol. 106, Issue 3. - P. 360-368.

8. Remote ischaemic preconditioning and sevoflurane postconditioning synergistically protect rats from myocardial injury induced by ischemia and reperfusion partly via inhibition TLR4/MyD88/NF-KB Signaling Pathway /
J. A. Zhang, J. B. Zhang, P. C. Yu [et al.] // Cellular Physiology and Biochemistry. - 2017. - Vol. 41. - P. 22-32.

9. Teoh N. C. Hepatic ischemia reperfusion injury: Pathogenic mechanisms and basis for hepatoprotection / N. C. Teoh, G. C. Farrell // Journal of Gastroenterology and Hepatology. - 2003. - Vol. 18 (8). - P. 891-902.

10. Inauen W. Mechanisms of cellular injury: potential sources of oxygen free radicals in ischemia/reperfusion / W. Inauen, M. Suzuki, D. N. Granger // Microcirculation, endothelium, and lymphatics. - 1989. - Vol. 5 (3-5). - P. 143-155.

11. Rochette L. Free radicals, lipid peroxidation and muscular ischemia / L. Rochette, V. Maupoil // Comptes Rendus des Seances de la Societe de Biologie. - 1992. Vol. 186 (3). - P. 252-262.

12. Погляди на тимчасові методи зупинки кровотечі в умовах бойових дій / В. С. Тарасюк, М. В. Матвійчук, І. В. Паламар [та ін.] // Вісник вінницького національного медичного університету. - 2017. - № 1, Ч. 2 (Т. 21). - С. 220-227.

13. Пінчук О. Військові медики на полі бою : навч. програма / О. Пінчук, В. Пінчук // [електронний ресурс]. Medsanbat. Info. - Версія 1. - K., 2015. URL: http://sergbukarevua.wixsite.com/voenlit/single-post/2016/11/06/\%D0 \%9D\%D0\%B0\%D0\%B2\%D1\%87\%D0\%B0\%D0\%BB\%D1\% 8C\%D0\%BD\%D0\%B0-\%D0\%BF\%D1\%80\%D0\%BE\%D0\%B 3\%D1\%80\%D0\%B0\%D0\%BC\%D0\%B0-\%D0\%92\%D1\%96 \%D0\%B9\%D1\%81\%D1\%8C\%D0\%BA\%D0\%BE\%D0\%B2 \%D1\%96-\%D0\%BC\%D0\%B5\%D0\%B4\%D0\%B8\%D0\%BA\% D0\%B8-\%D0\%BD\%D0\%B0-\%D0\%BF\%D0\%BE\%D0\% BB\%D1\%96-\%D0\%B1\%D0\%BE\%D1\%8E

14. Березан С. Тактична медицина для підрозділів спеціального призначення / С. Березан, С. Ротчук. - К. : ПП “МВЦ «Медінформ”, 2016. - 33 с. 
Огляди літератури, оригінальні дослідження, погляд на проблему, ювілеї

15. Model for skeletal muscle ischemia in rat hindlimb: evaluation of reperfusion and necrosis / S. A. Skjeldal, B. Grogaard, O. Reikeras [et al.] // European Surgical Research. - 1991. - Vol. 23 (5-6). - P. 355-365.

16. Haljamäe H. Human skeletal muscle energy metabolism during and after complete tourniquet ischemia / H. Haljamäe, E. Enger // Annals of Surgery. - 1975. - Vol. 182 (1). - P. 9-14.

17. Häggmark T. Time course of muscle metabolic changes during tourniquet ischemia in man / T. Häggmark, E. Jansson, E. Eriksson // International Journal of Sports Medicine. - 1981. - Vol. 2 (1). - P. 50-53.

18. Larsson J. Electrolyte changes in muscle tissue and plasma in tourniquet-ischemia / J. Larsson, J. Bergström // Acta Chirurgica Scandinavica. - 1978. - Vol. 144 (2). - P. 67-73.

19. The acute effects of tourniquet ischemia on tissue and blood gas tensions in the primate limb / S. H. Miller, R. J. Lung, W. P. Graham [et al.] // Journal of Hand Surgery. 1978. - Vol. 3 (1). - P. 11-20.

20. Effects of tourniquet ischemia and postischemic edema on muscle metabolism / S. H. Miller, G. Price, D. Buck [et al.] // Journal of Hand Surgery. - 1979. - Vol. 4 (6). P. 547-555.

21. Protective effect of low-grade hypothermia in experimental skeletal muscle ischemia / S. A. Skjeldal, B. C. Grogaard, L. B. Nordsletten [et al.] // European Surgical Research. - 1992. - Vol. 24 (4). - P. 197-203.

22. Local hypothermia during ischemia or reperfusion in skeletal muscles / S. Skjeldal, A. Torvik, L. Nordsletten [et al.] // Research in Experimental Medicine. - 1993. Vol. 193 (2). P. 73-80.

23. Contemporary outcomes of endovascular interventions for acute limb ischemia / R. M. Byrne, A. G. Taha, E. Avgerinos [et al.] // Journal of Vascular Surgery. - 2014. Vol. 59 (4). - P. 988-995.

24. Acute limb ischemia: contemporary approach / I. Fukuda, M. Chiyoya, S. Taniguchi, W. Fukuda // The Journal of Thoracic and Cardiovascular Surgery. - 2015. - Vol. 63 (10). P. 540-548.

\section{REFERENCES}

1. Abela, C.B., \& Homer-Vanniasinkham, S. (2003). Clinical implications of ischaemia-reperfusion injury. Pathopysiology, 9, 229-240.

2. Price, G.J., Miller, S.H., Kennedy, T.J., \& Graham, W.P. (1978). Acute and delayed effects of tourniquet ischemia on subfascial pressures and tissue gas tensions within muscles of the subhuman primate limb. Surgical Forum, 29, 612-615.

3. Nanobashvili, J., Neumayer, C., Fuegl, A., Blumer, R., Prager, M., Sporn, E., ... \& Huk, I. (2003). Development of "noreflow" phenomenon in ischemia/reperfusion injury: failure of active vasomotility and not simply passive vasoconstriction. European Surgical Research Journal, 35, 417-424.

4. Nanobashvili, J., Neumayer, C., Fuegl, A., Blumer, R., Prager, M., Sporn, E., ... \& Huk, I. (2003). Development of no-reflow phenomenon in ischemia/reperfusion injury: failure of active vasomotility and not simply passive vasoconstriction. European Surgical Research Journal, 35 (5), 417-424.
25. Effects of adrenomedullin and vascular endothelial growth factor on ischemia/reperfusion injury in skeletal muscle in rats / M. Kirisci, G. L. Oktar, C. Ozogul [et al.] // Journal of Surgical Research. - 2013. - Vol. 185 (1). - P. 56-63.

26. Protective effects of Sonic Hedgehog against ischemia/reperfusion injury in mouse skeletal muscle via AKT/mTOR/p70S6K Signaling / Q. Zeng, Q. Fu, X. Wang [et al.] // Cellular Physiology and Biochemistry. - 2017. Vol. 43 (5). - P. 1813-1828.

27. Effects of Daflon ${ }^{\circledR} 500 \mathrm{mg}$ on Postischemic Macromolecular Leak Syndrome in Striated Skin Muscle of the Hamster / D. Nolte, S. Pickelman, E. Schütze [et al.] // International Journal of Microcirculation. - 1997. - Vol. 17. -P. 6-10.

28. Effects of ascorbic Acid, alpha-tocopherol and allopurinol on ischemia-reperfusion injury in rabbit skeletal muscle: an experimental study / B. Erkut, A. Özyazıcıoğlu, B. S. Karapolat [et al.] // Drug Target Insights. - 2007. Vol. 2. - P. 249-258.

29. Pentoxifylline reduces skeletal muscle necrosis after acute hindlimb ischemia in rats / S. A. Skjeldal, K. Hvaal, L. Nordsletten [et al.] // European Surgical Research. 1994. - Vol. 26 (2). - P. 94-100.

30. The effects of pentoxifylline into the kidneys of rats in a model of unilateral hindlimb ischemia/reperfusion injury / R. Teruya, D. J. Fagundes, C. T. Oshima [et al.] // Acta Cirurgica Brasileira. - 2008. - Vol. 23 (1). - P. 29-35.

31. Moreira Neto A. A. Effects of cilostazol in kidney and skeletal striated muscle of Wistar rats submitted to acute ischemia and reperfusion of hind limbs / A. A. Moreira Neto, S. S. Junior Souza, V. L. Capelozzi [et al.] // Acta Cirurgica Brasileira. - 2012. - Vol. 27 (11). - P. 783-388.

32. Effects of vardenafil on the kidney of Wistar rats submitted to acute ischemia and reperfusion / R. C. Sousa, A. A. Neto Moreira, V. L. Capelozzi [et al.] // Acta Cirurgica Brasileira. - 2015. - Vol. 30 (5). - P. 339-344.

33. Does granulocyte depletion protect against ischaemic muscle necrosis? / S. Skjeldal, B. Grøgaard L. Nordsletten [et al.] // Scandinavian Journal of Clinical Laboratory Investigation. - 1994. - Vol. 54 (1). - P. 17-22.

5. Eltzschig, H.K. \& Collard, C.D. (2004). Vascular ischaemia and reperfusion injury. British Medical Bulletin, 70 (1), 71-86.

6. de Groot, H. \& Rauen, U. (2007). Ischemia-Reperfusion Injury: Processes in Pathogenetic Networks: A Review. Transplantation Proceedings, 39, 481-484.

7. Aslan, T., Turer, M.D., Joseph, A., \& Hill, M.D. (2010). Pathogenesis of myocardial ischemia-reperfusion injury and rationale for therapy. The American Journal of Cardiology, 106, 3, 360-368.

8. Zhang, J.A., Zhang, J.B., Yu, P.C. Chen, M.D., Peng, O.E., Wang, Z.F., \& Dong, N.A. (2017). Remote ischaemic preconditioning and sevoflurane postconditioning synergistically protect rats from myocardial injury induced by ischemia and reperfusion partly via inhibition TLR4/MyD88/NF-kB Signaling Pathway. Cellular Physiology and Biochemistry, 41, 22-32.

9. Teoh, N.C. \& Farrell, G.C. (2003). Hepatic ischemia reperfusion injury: Pathogenic mechanisms and basis for 
Огляди літератури, оригінальні дослідження, погляд на hepatoprotection. Journal of Gastroenterology and Hepatology, 18 (8), 891-902.

10. Inauen, W., Suzuki, M., \& Granger, D.N. (1989). Mechanisms of cellular injury: potential sources of oxygen free radicals in ischemia/reperfusion. Microcirculation, Endothelium, and Lymphatics, 5 (3-5), 143-155.

11. Rochette, L., \& Maupoil, V. (1992). Free radicals, lipid peroxidation and muscular ischemia. Comptes Rendus des Seances de la Societe de Biologie, 186 (3), 252-262.

12. Tarasiuk, V.S., Matviichuk, M.V., Palamar, I.V., Korolova, N.D., Poliarush, V.V., Podolian, V., ... \& Dubovyi, O. (2017). Pohliady na tymchasovi metody zupynky krovotechi $v$ umovakh boiovykh dii [Views on temporary methods of stopping bleeding in combat]. Visnyk vinnytskoho natsionalnoho medychnoho universytetu - Bulletin of the Vinnytsia National Medical University, 1, (2, 21), 220-227 [in Ukrainian].

13. Pinchuk, O., \& Pinchuk, V. (2015). Viiskovi medyky na poli boiu: navch. prohrama [Military doctors on the battlefield: educational program]. Medsanbat. Info, Version 1, Kyiv. Retrieved from: http://sergbukarevua.wixsite.com/ voenlit/single-post/2016/11/06/\%D0\%9D\%D0\%B0\%D0\% B2\%D1\%87\%D0\%B0\%D0\%BB\%D1\%8C\%D0\%BD\%D0 \%B0-\%D0\%BF\%D1\%80\%D0\%BE\%D0\%B3\%D1\%80\%D0 \%B0\%D0\%BC\%D0\%B0-\%D0\%92\%D1\%96\%D0\%B9\%D1 \%81\%D 1\%8C\%D0\%BA\%D0\%BE\%D0\%B2\%D 1\%96\%D0\%BC\%D0\%B5\%D0\%B4\%D0\%B8\%D0\%BA\%D0\%B8\%D0\%BD\%D0\%B0-\%D0\%BF\%D0\%BE\%D0\%BB\%D1\%96\%D0\%B1\%D0\%BE\%D1\%8E [in Ukrainian]

14. Berezan, S., \& Rotchuk, S. (2016). Taktychna medytsyna dlia pidrozdiliv spetsialnoho pryznachennia [Tactical medicine for special units]. Kyiv: PP "MVTs "Medinform" [in Ukrainian].

15. Skjeldal, S.A., Grogaard, B., Reikeras, O., Müller, C., Torvik, A., \& Svindland, A. (1991). Model for skeletal muscle ischemia in rat hindlimb: evaluation of reperfusion and necrosis. European Surgical Research, 23 (5-6), 355-365.

16. Haljamäe, H. \& Enger, E. (1975). Human skeletal muscle energy metabolism during and after complete tourniquet ischemia. Annals of Surgery, 182 (1), 9-14.

17. Häggmark, T., Jansson, E., \& Eriksson, E. (1981). Time course of muscle metabolic changes during tourniquet ischemia in man. International Journal of Sports Medicine, 2 (1), 50-53.

18. Larsson, J. \& Bergström, J. (1978). Electrolyte changes in muscle tissue and plasma in tourniquet-ischemia. Acta Chirurgica Scandinavica, 144 (2), 67-73.

19. Miller, S.H., Lung, R.J., Graham, W.P., Davis, T.S., \& Rusenas, I. (1978). The acute effects of tourniquet ischemia on tissue and blood gas tensions in the primate limb. Journal of Hand Surgery, 3 (1), 11-20.

20. Miller, S.H., Price, G., Buck, D., Neeley, J., Kennedy, T.J., Graham, W.P., \& Davis, T.S. (1979). Effects of tourniquet ischemia and postischemic edema on muscle metabolism. Journal of Hand Surgery, 4 (6), 547-555.

21. Skjeldal, S.A., Grogaard, B.C., Nordsletten, L.B., Reikeras, O.A., Svindland, A.D., \& Torvik, A.D. (1992). Protective effect of low-grade hypothermia in experimental ske- letal muscle ischemia. European Surgical Research, 24 (4), 197-203.

22. Skjeldal, S., Torvik, A., Nordsletten, L., Kirkeby, O.J., Grogaard, B., Svindland, A., Reikeras, O. (1993). Local hypothermia during ischemia or reperfusion in skeletal muscles. Research in Experimental Medicine, 193 (2), 73-80.

23. Byrne, R.M., Taha, A.G., Avgerinos, E., Marone, L.K., Makaroun, M.S., \& Chaer, R.A. (2014). Contemporary outcomes of endovascular interventions for acute limb ischemia. Journal of Vascular Surgery, 59 (4), 988-995.

24. Fukuda, I., Chiyoya, M., Taniguchi, S., \& Fukuda, W. (2015). Acute limb ischemia: contemporary approach. The Journal of Thoracic and Cardiovascular Surgery, 63 (10), 540-548.

25. Kirisci, M., Oktar, G.L., Ozogul, C., Oyar, E.O., Akyol, S.N., Demirtas, C.Y., \& Arslan, M. (2013). Effects of adrenomedullin and vascular endothelial growth factor on ischemia/reperfusion injury in skeletal muscle in rats. Journal of Surgical Research, 185 (1), 56-63.

26. Zeng, Q., Fu, Q., Wang, X., Zhao, Y., Liu, H., Li, Z., \& Li, F. (2017). Protective effects of Sonic Hedgehog against ischemia/reperfusion injury in mouse skeletal muscle via AKT/mTOR/p70S6K Signaling. Cellular Physiology and Biochemistry, 43 (5), 1813-1828.

27. Nolte, D., Pickelman, S., Schütze, E., Möllmann, M., \& Messmer, K. (1997). Effects of Daflon ${ }^{\circledR} 500 \mathrm{mg}$ on Postischemic Macromolecular Leak Syndrome in Striated Skin Muscle of the Hamster. International Journal of Microcirculation, 17, 6-10.

28. Erkut, B., Özyazıcıoğlu, A., Karapolat, B.S., Koçoğulları, C.U., Keles, S., Ateş, A., ... \& Kocak, H. (2007). Effects of ascorbic Acid, alpha-tocopherol and allopurinol on ischemia-reperfusion injury in rabbit skeletal muscle: an experimental study. Drug Target Insights, 2, 249-258.

29. Skjeldal, S.A., Hvaal, K., Nordsletten, L., Aasen A. O., Reikeras, O., \& Torvik, A. (1994). Pentoxifylline reduces skeletal muscle necrosis after acute hindlimb ischemia in rats. European Surgical Research, 26 (2), 94-100.

30. Teruya, R., Fagundes, D.J., Oshima, C.T., Brasileiro, J.L., Marks, G., Ynouye, C.M., \& Simoes, M.J. (2008). The effects of pentoxifylline into the kidneys of rats in a model of unilateral hindlimb ischemia/reperfusion injury. Acta Cirurgica Brasileira, 23 (1), 29-35.

31. Moreira Neto, A.A., Junior Souza, S.S., Capelozzi, V.L., Parra-Cuentas, E.R., Junior Schmidt, A.F., \& Francisco, O.R. (2012). Rodrigues effects of cilostazol in kidney and skeletal striated muscle of Wistar rats submitted to acute ischemia and reperfusion of hind limbs. Acta Cirurgica Brasileira, 27 (11), 783-388.

32. Sousa, R.C., Neto Moreira, A.A., Capelozzi, V.L., AbSaber, A.M., \& Rodrigues, O.R. (2015). Effects of vardenafil on the kidney of Wistar rats submitted to acute ischemia and reperfusion. Acta Cirurgica Brasileira, 30 (5), 339-344.

33. Skjeldal, S., Grogaard, B., Nordsletten, L., Torvik, A., Svindland, A., \& Reikaras, O. (1994). Does granulocyte depletion protect against ischaemic muscle necrosis? Scandinavian Journal of Clinical Laboratory Investigation, 54 (1), 17-22. 
Огляди літератури, оригінальні дослідження, погляд на проблему, ювілеї

\title{
МОРФОЛОГІЧНІ ТА МЕТАБОЛІЧНІ ЗМІНИ, СПРИЧИНЕНІ СИНДРОМОМ ІШЕМІЇ-РЕПЕРФУЗІЇ, ТА ОСОБЛИВОСТІ ТЕРАПЕВТИЧНОГО ВПЛИВУ НА НИХ
}

\author{
○Н. В. Волотовська, А. Ю. Годована, Д. Нканса Аппіа
}

ДВНЗ «Тернопільський державний медичний університет імені І. Я. Горбачевського мОз України»

РЕзЮМЕ. У статті проаналізовано літературні джерела щодо причин та особливостей розвитку синдрому ішемії-реперфузії, а також прояви патофізіологічних змін за умов впливу чинників зовнішнього середовища. Досліджено вплив лікувально-профілактичних заходів, направлених на зменшення обсягу ураження. Коли йдеться про живлення кожного органа, то мають на увазі приплив оксигенованої крові, що містить також і нутрієнти. Ішемія, будучи станом обмеження чи припинення кровопостачання, має численні причини - гострі та хронічні.

Метою дослідження $\epsilon$ систематизація причин і особливостей синдрому ішемії-реперфузії, а також прояви патофізіологічних змін під впливом факторів навколишнього середовища.

Зміни, які викликає ішемія, можуть розвиватися десятиріччями (кардіоваскулярні та цереброваскулярні хвороби). А $є$ і такі, що виникають на тлі порівняно короткого проміжку часу й пов'язані із раптовим припиненням кровопостачання (емболії, тромбоз, синдром довготривалого стискання та один із його різновидів -ускладнення, що виникають на тлі використання кровоспинного джгута, а також турнікета з метою припинення кровопостачання органа під час операції).

Саме вид ішемії, який призводить до відновлення кровотоку, спричиняє особливий феномен, коли відновлення кровопостачання ішемізованої тканини призводить до ще сильнішого ушкодження тканин, ніж ті, що виникають на тлі ізольованої ішемії. Це явище отримало назву синдрому ішемії-реперфузії. Симптомами гострої ішемії кінцівки $є$ біль, набряк, втрата функції та порушення стану нерва. Але в складних випадках це може призвести до ураження всього організму.

Ключові словА: ішемія; ішемія-реперфузія; кровотеча; турнікет; скелетні м'язи; експеримент; некроз; апоптоз.

\section{МОРФОЛОГИЧЕСКИЕ И МЕТАБОЛИЧЕСКИЕ ИЗМЕНЕНИЯ, ВЫЗВАННЫЕ СИНДРОМОМ ИШЕМИИ-РЕПЕРФУЗИИ, И ОСОБЕННОСТИ ТЕРАПЕВТИЧЕСКОЙ КОРРЕКЦИИ}

\author{
๑Н. В. Волотовская, А. Ю. Годована, Д. Нканса Аппиа
}

ГВУз «Тернопольский государственный медицинский университет имени И. Я. Горбачевского МОЗ Украины»

РЕЗЮМЕ. В статье анализируются литературные данные о причинах и характеристиках развития синдрома ишемии-реперфузии, а также проявления патофизиологических изменений под влиянием факторов окружающей среды. Исследовано влияние лечебно-профилактических мероприятий, направленных на снижение патологических проявлений. Когда речь идет о питании каждого органа, то имеется в виду приток оксигенированной крови, которая также содержит и нутриенты. Ишемия, будучи состоянием ограничения или прекращения кровоснабжения, имеет многочисленные причины - острые и хронические.

Целью исследования является систематизация причин и особенностей синдрома ишемии-реперфузии, а также проявлений патофизиологических изменений под влиянием факторов окружающей среды.

Изменения, которые вызывает ишемия, могут развиваться десятилетиями (кардиоваскулярные и цереброваскулярные болезни). А есть и такие, которые возникают на фоне сравнительно короткого промежутка времени и связаны с внезапным прекращением кровоснабжения (эмболии, тромбоз, синдром длительного сдавления и один из его разновидностей - осложнения, возникающие на фоне использования кровоостанавливающего жгута, а также турникета с целью прекращения кровоснабжения органа во время операции).

Именно вид ишемии, который приводит к восстановлению кровотока, вызывает особый феномен, когда восстановление кровоснабжения ишемизированной ткани приводит к еще более сильному повреждению тканей, чем те, котрые возникают на фоне изолированной ишемии. Это явление получило название синдрома ишемииреперфузии. Симптомами острой ишемии конечности являются боль, отек, потеря функции и нарушение состояния нерва. Но в сложном состоянии это может привести к поражению всего тела.

КЛЮчЕВЫЕ СЛОВА: ишемия; ишемия-реперфузия; кровотечение; жгут; скелетные мышцы; експеримент; некроз; апоптоз. 